\title{
Estatísticas oficiais, violência e crime no Brasil
}

\author{
Arthur Trindade M. Costa ${ }^{1}$ \\ Renato Sérgio de Lima
}

\section{Introdução}

Nos últimos 20 anos verificou-se um crescimento extraordinário dos estudos sobre violência e criminalidade no Brasil. Partindo de diferentes abordagens teóricas e utilizando uma grande variedade de técnicas de pesquisa, esses trabalhos passaram a constituir um campo de estudo específico nas ciências sociais. Em boa medida, o surgimento desse campo deveu-se à centralidade que o tema alcançou na vida política e social do país.

A grande variedade de temas e objetos de pesquisa contemplados pelos estudos nesse campo já foi analisada em diversos trabalhos (BARREIRA; ADORNO, 2010; KANT DE LIMA; MISSE; MIRANDA, 2000; LIMA, 2011; SOUZA, 2005; ZALUAR, 1999). Em geral, são estudos sobre o funcionamento do sistema de justiça criminal e suas instituiçôes (especialmente as polícias), e sobre as novas dinâmicas sociais que emergem da intensificação de práticas violentas. Mais recentemente, Campos e Alvarez (2017), realizando um balanço da produção científica brasileira sobre violência e punição no período de 2000 a 2016, agruparam esses estudos em três temáticas distintas: (1) estudos sobre políticas públicas de segurança; (2) estudos sobre violências e sociabilidades; e (3) estudos sobre punição e prisóes.

Neste artigo não pretendemos revisar a produção acadêmica brasileira sobre violência e criminalidade. Nosso objetivo é de outra natureza: discutiremos os principais problemas e limites metodológicos das pesquisas que utilizaram estatísticas oficiais para explicar fenômenos relacionados a violência, criminalidade e funcionamento do sistema de justiça criminal. Analisaremos as pesquisas que utilizaram dados oficiais provenientes dos registros administrativos e de surveys, incluindo estatísticas criminais, pesquisas de vitimização ou percepção e estatísticas judiciais. Também analisaremos alguns estudos que avaliaram políticas de segurança pública.

A maior parte dos trabalhos analisados foi extraída da base de artigos construída para o projeto editorial da ABCP. A base contém artigos publicados entre 2000 e 2016 nos periódicos nacionais classificados pela Capes como A1, A2 ou B1 em pelo menos duas das três áreas das ciências sociais. A base contém artigos publicados em 49 periódicos. ${ }^{3}$

1 Arthur Trindade M. Costa é professor de sociologia da Universidade de Brasília (UnB) e pesquisador 2 CNPq. E-mail: arthurtmcosta@gmail.com

2 Renato Sérgio de Lima é professor do Departamento de Gestão Pública da Escola de Administração de Empresas de São Paulo da Fundação Getúlio Vargas (FGV-SP) e pesquisador 2 CNPq. E-mail: renato.lima@fgv.br

3 Os autores são gratos a Luís Flávio Sapori, Cleber da Silva Lopes, André Zanetic e Gláucio A. D. Soares, que gentilmente disponibilizaram a base de artigos construída para o projeto editorial da $\mathrm{ABCP}-30$ Anos da Constituição de 1988. 


\section{Os limites das estatísticas criminais baseadas em registros administrativos}

A qualidade das pesquisas sobre funcionamento do sistema de justiça criminal e de segurança pública não depende somente dos modelos teóricos utilizados para explicar os fenômenos. Ela depende também da sua robustez metodológica, que, além das estratégias e técnicas de pesquisa, está sujeita fundamentalmente à qualidade dos dados utilizados. Ao discutir qualidade, estamos propondo uma reflexão sobre o estatuto epistemológico de dados e informaçóes utilizados pela academia brasileira para produzir conhecimento sobre medo, crime e violência, bem como sobre o funcionamento das instituiçôes de justiça criminal e de segurança pública.

No plano geral, este é um debate mais comum ao campo de estudos da ciência da informação e das estatísticas públicas, que tem em Nelson Senra $(1996,1998,2000)$ uma de suas referências mais conhecidas. Porém, aproveitando a forma como a discussáo sobre a qualidade da informação é feita no campo aplicado das políticas públicas e da produção de indicadores sociais, é possível esquematizá-la em um conjunto de 12 atributos desejados para tornar dados e indicadores inteligíveis e passíveis de serem técnica e cientificamente apropriados pela universidade, pelas políticas públicas e/ou por qualquer outro segmento da sociedade (JANNUZZI, 2017).

Assim, se olharmos com atenção o Quadro 1, perceberemos que por trás da produção de dados oficiais e, em especial, do uso que deles é feito pela pesquisa acadêmica no Brasil, há uma série de questôes de natureza epistemológica que vai dar maior ou menor validade externa às análises empreendidas. E, desse modo, a disponibilidade de estatísticas varia conforme o grau de objetivação do fenômeno descrito. Portanto, as variáveis definidas por meio de normas legais claras são mais fáceis de serem medidas do que as percepçóes ou, mesmo, os atos ilegais, mas que ainda estáo invisíveis ao sistema de segurança e justiça, como violências cometidas contra grupos vulneráveis e/ou grupos específicos da população (LIMA, 2011).

\section{Quadro 1 \\ Propriedades desejadas das estatísticas oficiais}

\begin{tabular}{|c|c|}
\hline Relevância & Inteligibilidade \\
\hline Validade & Comunicabilidade \\
\hline Confiabilidade & Factibilidade \\
\hline Grau de cobertura & Periodicidade \\
\hline Sensibilidade & Desagregabilidade \\
\hline Especificidade & Comparabilidade \\
\hline
\end{tabular}

Fonte: Adaptado de Jannuzzi (2017)

Isso significa dizer que, ao contrário de revelar fatores criminógenos e identificar situações sociais que favoreçam a ocorrência de crimes, as estatísticas produzidas a partir dos registros administrativos das instituiçóes de justiça criminal e segurança pública (boletins de ocorrência, inquéritos, processos, entre outros) referem-se à forma como os crimes e os criminosos são socialmente construídos e, portanto, exigem a compreensão dos processos sociais de identificaçáo de uma ocorrência criminal (o que é crime?) e do autor da conduta desviante (quem é o criminoso?), e dos processos formais de processamento dos conflitos criminais e da puniçáo (tratamento legal) (LIMA, 2011).

Várias são as implicaçôes dessas preocupaçóes, como veremos na sequência, mas cabe destacar, aqui, que a existência de séries históricas de estatísticas criminais tem a expectativa de subsidiar o desenho e a implementação de políticas públicas mais eficientes por meio da mensuração daquilo que chega ao conhecimento oficial do Estado e, ainda, das 
percepçóes que os indivíduos têm sobre crimes e criminosos. Nesse processo, a produção de estatísticas criminais tem de reconhecer que as categorias e classificaçóes são socialmente construídas em cada localidade. Em outras palavras, a definição do que é crime e de quem seriam os criminosos é, usualmente, determinada pelas leis, mas vários outros fatores sociais influenciam os processos de produção e seleção dos dados que vão motivar a agenda das instituiçôes de segurança pública (LIMA, 2011; LIMA; BORGES, 2014).

As pesquisas sobre segurança pública e justiça criminal utilizam, fundamentalmente, duas fontes de estatísticas oficiais: (1) os boletins de ocorrência (BO) elaborados pelas policiais civis estaduais e (2) as declaraçóes de óbito confeccionadas nos hospitais e unidades de atendimento de emergência. As informações contidas nos BO irão alimentar as estatísticas estaduais de segurança pública e as declarações de óbito fomentarão as estatísticas do Ministério da Saúde.

O BO funciona como uma "ficha de entrada" no processo de trabalho policial, sendo o principal instrumento para produzir e registrar informaçôes e gerar estatísticas criminais. Ele é a primeira "entrevista com o crime", isto é, o primeiro recurso de notificação de um delito, precedendo, inclusive, as atividades policiais de verificação, qualificação e fundamentação das informaçóes obtidas inicialmente (MUNIZ, 2000). Dessa forma, podemos entender o $\mathrm{BO}$ como uma narrativa mais abrangente, porém provisória, de um episódio comunicado à Polícia Civil. Nesse sentido, as informaçôes coletadas nos $\mathrm{BO}$ refletem, antes de tudo, um momento do ciclo da atividade da Polícia Civil (LIMA, 2011; LIMA; BORGES, 2014; MUNIZ, 2000).

Diferentes autores já discutiram os problemas relacionados à utilização dos $\mathrm{BO}$ como fonte de dados das pesquisas em segurança pública, sobretudo no que se refere à qualidade das informaçóes contidas nesses registros (BEATO, 1998, 2000; CANO, 2000; KAHN, 1998, 2000; MIRANDA; PITA, 2011; MISSE, 1997). Analisando o fluxo das informações produzidas a partir dos BO, Dirk (2007) sugere que há três dimensões distintas na geração das estatísticas criminais no Brasil: (1) dos acontecimentos, (2) do acionamento das instituiçôes, e (3) do fluxo dos registros de ocorrência.

Após um acontecimento, a(s) vítima(s) ou testemunha(s) pode $(\mathrm{m})$ notificar o fato à polícia ou não. Assim, essa primeira dimensão contempla tanto a ocorrência dos eventos quanto as subnotificaçôes. A subnotificação se refere aos casos em que o evento criminal não foi comunicado às autoridades policiais, ainda que, por sua natureza, devessem ser levados ao conhecimento da polícia. Essa subnotificação pode ocorrer sem nenhum conhecimento das autoridades - Polícia Militar, Guarda Municipal ou Polícia Civil - ou com o conhecimento de alguma delas. Dirk (2007, p. 40) denomina o primeiro caso de "subnotificação desconhecida, pois nenhum dos agentes da segurança pública tomou conhecimento do fato, ou ainda, o evento ocorreu e náo houve nenhum acionamento institucional”, como roubo de celular ou violência doméstica não comunicados às autoridades policiais.

A segunda dimensão apontada por Dirk (2007) é denominada "acionamento das instituiçóes”, ou seja, a(s) vítima(s) ou testemunha(s) entra $(\mathrm{m})$ em contato com as autoridades (polícias e/ou guardas municipais). $\mathrm{O}$ autor ressalta que esta dimensão não garante o registro do fato delituoso na delegacia de Polícia Civil. Se isso acontecer, então temos uma subnotificação conhecida, ou seja, quando o evento criminoso chega ao conhecimento das autoridades, mas não chega a ser registrado, por diferentes motivos. $\mathrm{O}$ não registro do fato delituoso na delegacia configura um sub-registro. 
Finalmente, quando o evento é registrado na delegacia de Polícia Civil, a ocorrência segue para a dimensão do fluxo dos registros de ocorrência. Nesta dimensão, o policial civil registra a ocorrência e, dependendo do caso, procede à verificação das informaçôes para constatação do fato. Quando o fato é registrado em delegacia de polícia é gerado um BO - ou Registro de Ocorrência (RO), dependendo do estado brasileiro. Temos então três categorias de crimes: (1) crimes que náo são conhecidos (subnotificação desconhecida); (2) crimes conhecidos e náo registrados (subnotificação conhecida); (3) crimes que são conhecidos e registrados. As estatísticas que são publicadas pertencem à terceira categoria, e são conhecidas como "estatísticas oficiais". As duas primeiras categorias são conhecidas como cifras ocultas; obscuras (darknumber) ou taxas de sub-registro ou subnotificação.

No cenário internacional, o debate sobre a validade das estatísticas criminais reportadas à polícia não é recente (CANTOR; LYNCH, 2000; SKOGAN, 1974, 1984). Existem diferentes opinióes sobre a gravidade dos problemas associados à forma como os dados sáo coletados e à subnotificação das ocorrências criminais. De um lado, muitos pesquisadores creem que as estatísticas criminais estão corrompidas por erros de medição resultantes de diferenças nas práticas de trabalho das polícias ou por falta de treinamento dos responsáveis pela coleta das informaçóes primárias dos fatos criminosos. Por outro lado, alguns estudiosos preferem assumir que, ainda que tais problemas existam, eles não necessariamente impedem o uso das estatísticas criminais para determinar a eficácia de políticas destinadas a reduzir a criminalidade.

Segundo May (2011), para que as estatísticas compiladas em instituiçôes oficiais sejam válidas e confiáveis é necessário reunir pelo menos três critérios. O primeiro é que os coletores da informação primária - em geral, policiais - devem respeitar as mesmas categorias para os mesmos incidentes, ou seja, náo deve haver critério pessoal, mas padronizado no momento do registro ou da classificação. $\mathrm{O}$ segundo diz que as estatísticas devem ser mutuamente exclusivas, de modo que um incidente não venha a ser classificado duas ou mais vezes. E o terceiro critério é que a classificação deve ser exaustiva, para que todos os crimes sejam contabilizados.

Seguindo esses critérios, então, podemos listar alguns problemas que as autoridades policiais brasileiras enfrentam para coletar e registrar as ocorrências de crimes e identificar as vítimas e os criminosos. Primeiro, a informação não é coletada de forma sistemática. Em alguns estados, as organizações policiais não produzem estatísticas mensais sobre suas atividades. Há estados em que não há periodicidade na divulgação das estatísticas criminais, impossibilitando a construção de séries históricas.

Segundo, algumas estatísticas criminais não possuem informaçóes detalhadas sobre o crime e suas circunstâncias. Em muitos casos não há registro estatístico sobre o dia, a hora e o local em que o crime ocorreu. Em geral, não existem muitas informaçóes sobre a vítima ou, quando obtidas, essas informaçóes não são de qualidade. Além da idade e do sexo da vítima, seria muito interessante saber a cor, o estado civil, a renda, a profissão etc. Também não há informações sobre os agressores e pouco se sabe sobre a relação entre a vítima e o agressor.

Terceiro, há pouco controle das cifras ocultas. $\mathrm{O}$ fato de haver sobrerrepresentação de alguns crimes devido a duplicação de registro e subnotificação não é um problema em si. As dificuldades surgem devido à ausência de pesquisas de vitimização destinadas a investigar as cifras ocultas dos registros criminais, ou seja, o percentual de casos que, por diferentes razóes, não chegam ao conhecimento oficial das polícias e do Estado. As cifras ocultas são um 
complemento às estatísticas criminais baseadas nos registros policiais e ganharam força a partir da aceitação do fato de que crimes e criminosos, longe de serem fatos em si, são construçóes sociais e estão sujeitos a uma série de processos sociais, políticos e culturais que precisam ser mais bem mensurados e analisados quando da investigação acerca dos seus determinantes e do desenho de políticas públicas (PEIXOTO; SOUZA; LIMA, 2012).

Quarto, não existe uniformidade na classificação dos delitos e, em alguns casos, o registro é feito de forma discricional. Isto é, existem problemas de definição e detecção. Para tanto, a Secretaria Nacional de Segurança Pública (Senasp) desenvolveu um sistema nacional de classificação de ocorrências criminais, com o objetivo de padronizar a classificação das estatísticas criminais entre os estados, mas ele ainda não foi plenamente adotado por todas as Unidades da Federação (UF). Além disso, ele é rejeitado pela inexistência de mecanismos formais e legais de coordenação do sistema de segurança pública e de uma agência legalmente autorizada para produzir e publicar dados nacionais sobre crime e polícias no país.

Diante do exposto, podemos dizer que as estatísticas de criminalidade no Brasil são pouco confiáveis, já que não existe sistematização, e a cultura da informação em segurança pública ainda não é definida como prioridade pelos gestores, o que significa que o processo de geração das estatísticas é falho na origem. Sendo assim, rejeitamos a "objetividade" que as estatísticas precisam apresentar, e observamos que os dados não são válidos nem confiáveis (CERQUEIRA; LOBÃO; CARVALHO, 2005). Logo, qualquer análise, conclusão e decisão com base nessas estatísticas não será totalmente útil se não se conhecer bem seus problemas e não analisar os dados crítica e minuciosamente. É digno de nota que essas questóes se referem mais especificamente às estatísticas criminais no contexto nacional e não nos níveis estaduais. Existem estados que possuem sistemas de informação mais consolidados, apesar de também apresentarem alguns dos problemas técnico-metodológicos na geração da informaçáo. Por outro lado, existem estados que não possuem controle e crítica sobre seus registros oficiais.

Sobre os estados com tradição local de produção de dados criminais e registros policiais, Minas Gerais, São Paulo e Rio de Janeiro se destacam, já que, além de possuírem alguns dos sistemas de informação mais antigos do país, concentram boa parte da produção das ciências sociais sobre violência, conforme demonstrou o levantamento feito por Vasconcelos (2015). Nesse processo, alguns centros de pesquisa, como o Centro de Estudos de Criminalidade e Segurança Pública da Universidade Federal de Minas Gerais, ganharam destaque nos anos 1990 e começo dos 2000 como espaços de mediação entre conhecimento acadêmico e pesquisa aplicada às políticas públicas, sobretudo no desenvolvimento de técnicas e de ferramentas de análise criminal e uso de estatísticas oficias e de surveys, que depois foram sendo disseminadas para todas as corporações policiais do Brasil.

Outra fonte de dados utilizada pelas pesquisas em segurança pública é o Sistema de Informaçôes sobre Mortalidade (SIM), que foi criado em 1976 pelo Ministério da Saúde com o objetivo de implementar um sistema nacional de informaçôes para o setor de saúde. O SIM abrange todas as regióes do país, e pode ser analisado em níveis nacional, estadual ou municipal. O instrumento utilizado para captação dessas informações é a declaração de óbito. De acordo com a legislação vigente no Brasil, nenhum sepultamento pode ser realizado sem essa declaração, que deve ser preenchida com base em atestado médico ou, na ausência de médico, por duas pessoas qualificadas que tenham presenciado ou constatado a morte. 
As causas externas ou mortes violentas são declaradas em formulário padronizado, de preenchimento obrigatório pelos médicos legistas. Vale ressaltar que a definição de morte violenta dada pelo SIM é diferente da dada pelas polícias. Pelo SIM, os homicídios são definidos segundo a Classificação Internacional de Doenças (CID-10), enquanto para as polícias a definição é feita segundo o Código Penal. Com isso, por exemplo, as mortes por homicídio classificadas pelo SIM abrangem mais de um tipo de morte violenta registrado pelas polícias. Deste modo, as taxas de homicídio contabilizadas pelos dados da saúde deveriam ser sempre maiores que as contabilizadas pelas polícias, uma vez que a polícia não registra como homicídios os casos em que a vítima não morre imediatamente após a agressão.

Outra diferença entre as duas fontes é que, para a polícia, os dados se referem ao local da ocorrência do fato, enquanto para o SIM se referem ao local do óbito. Por exemplo, suponha-se que um indivíduo tenha levado um tiro no município $\mathrm{Y}$ e sido levado para um hospital no município X, onde faleceu. Para a polícia, o crime ocorreu no município $Y$, enquanto na saúde a morte é registrada no município X. Logo, não é possível comparar informaçóes entre as duas fontes de dados. Caso seja feito um estudo com os dados da saúde, é importante considerar que os registros se referem ao local da morte e náo ao local de ocorrência do crime, que é o mais importante a se considerar num estudo de segurança pública.

Apesar das diferenças entre o SIM e as estatísticas criminais oriundas das polícias, é interessante comparar as tendências e verificar o quanto elas coincidem. Esse tipo de comparação entre diferentes fontes, certamente serve para considerar a confiabilidade dos dados e confirmar a validade dessas fontes como instrumentos de medição, pelo menos para a análise de tendência geral. Não há uma fonte melhor do que outra, mas há fontes que precisam ser tomadas de forma complementar e a partir dos propósitos de cada uma delas e da pesquisa que se pretende produzir.

\section{Contando as mortes}

O extraordinário crescimento do número de homicídios no Brasil fez com que vários pesquisadores se esforçassem para explicar o fenômeno e entender os diversos aspectos associados às mortes violentas. Em função da fragilidade dos dados produzidos pelas polícias e sistematizados pelo Ministério da Justiça, a maior parte das pesquisas sobre homicídios utilizou as informaçóes do Ministério da Saúde. Em números absolutos, o SIM contabilizou 59.080 homicídios em 2015 contra 13.910 em 1980. Entre 1980 e 2015, a taxa de homicídios por 100 mil habitantes aumentou $147 \%$, saltando de 11,7 para 28,9.

Embora esse aumento seja uma tendência geral, o quadro náo é homogêneo, apresentando importantes variaçóes. Podemos observar dois períodos distintos: no primeiro, de 1980 a 2000, as taxas de homicídio tiveram um crescimento acentuado de 128,2\%; a partir daí o ritmo de crescimento diminuiu - no segundo período, de 2000 a 2015, a taxa cresceu 8,2\%, pouco se comparado com o período anterior.

As variaçóes nas taxas de homicídio podem ser mais bem percebidas se compararmos as regióes brasileiras. Até 2005, as regióes Sudeste e Centro-Oeste apresentaram taxas superiores à média nacional. A partir de 2000, o quadro mudou bastante: as regióes Norte, Nordeste e Centro-Oeste passaram a apresentar taxas superiores à média nacional, enquanto Sul e Sudeste registraram taxas menores. Apesar dessa importante variação regional, ainda são poucos os estudos que se concentram em analisar o crescimento dos homicídios nessas três regióes. A regiāo Nordeste vem apresentando crescimento constante dos homicídios desde 1996. 
Os estados de Pernambuco, Alagoas e Bahia se destacam, sendo responsáveis por praticamente dois terços dos homicídios da região (NÓBREGA JUNIOR, 2010).

As pesquisas mostram uma forte associação entre a densidade demográfica e os homicídios (BEATO et al., 2001; CANO; SANTOS, 2001). Após analisar as taxas de homicídio em diferentes países, Soares (2008, p. 71) sugere que a "rapidez da urbanizaçáo em países com recursos escassos fez com que as cidades crescessem sem infraestrutura adequada - hospitais, escolas, polícia, empregos, recursos sanitários etc.".

Até 2000, o crescimento da taxa de homicídios foi mais acentuado nas 10 maiores regióes metropolitanas do país. Nesse ano, essas regiốes concentravam $35,6 \%$ da população brasileira e respondiam por $59,3 \%$ do número total de homicídios. Em 2010, as 10 maiores regiôes responderam por $36 \%$ dos homicídios registrados no país. Essa desconcentração de mortes nas regióes levou alguns analistas à interpretaçáo equivocada de que estaria ocorrendo uma interiorização do fenômeno, supondo uma migraçẫo do crime organizado. A ideia é equivocada porque essa desconcentração deveu-se principalmente à reduçáo dos homicídios na Regiāo Metropolitana de São Paulo (ANDRADE; DINIZ, 2013). Considerando a distribuiçâo de homicídios por cidades brasileiras, verifica-se que eles seguem concentrados, mas não mais nas capitais e sim nos demais municípios que compóem as regióes metropolitanas.

Continuam sendo uma grande incógnita os fatores que explicam o espantoso crescimento da violência letal nas últimas décadas. De forma geral, os estudos sobre os fatores determinantes dos homicídios se concentraram em explorar três diferentes aspectos: (1) o desenvolvimento econômico; (2) o perfil socioeconômico das vítimas; e (3) os aspectos ecológicos relacionados ao local das mortes.
Nem a melhoria dos índices de escolaridade nem a reduçáo da pobreza verificadas no período afetaram as taxas de homicídio. Esse quadro indica que precisamos reexaminar cuidadosamente a ideia de que há estreita correlaçáo entre escolaridade, pobreza e violência. A relação automática entre desigualdade e violência também é contestada em vários estudos (SOARES, 2008; VASCONCELOS; COSTA, 2005).

Tampouco a relação entre desemprego e violência se sustenta empiricamente. Além disso, estudos têm verificado que a maioria da população penitenciária brasileira era oriunda do mercado informal de emprego. Boa parte dessa população jamais teve carteira profissional assinada. Também não se verifica a relação entre desigualdade social e aumento da violência. Embora o número de homicídios tenha aumentado mais de $130 \%$ últimos 20 anos, a concentração de renda no Brasil tem permanecido quase a mesma nesse período (BEATO, 1998; CANO; SANTOS, 2001; SAPORI; WANDERLEY, 2001).

Para Soares (2008), os estudos que associam desenvolvimento econômico e homicídios não se sustentam empiricamente, posto que os conceitos de desenvolvimento, crescimento e modernização são muito vagos. Isso revela a necessidade de aperfeiçoamento teórico dessas pesquisas para dar conta de processos sociais mais complexos, que não se esgotam na noção de desenvolvimento econômico e social.

A distribuição dos homicídios quanto a sexo, idade e cor das vítimas apresenta um quadro com poucas variaçóes. Os estudos mostram que as principais vítimas continuam sendo os homens jovens negros, residentes na periferia das grandes cidades brasileiras, sendo a arma de fogo o principal instrumento utilizado para a perpetraçáo do ato violento. Os bairros mais pobres, onde a prestação de serviços públicos é mais precária, são aqueles que apresentam maior incidência de 
homicídios (ANDRADE; LISBOA, 2000; LIMA; PEIXOTO; DURANTE, 2004; SANTOS et al., 2001; VASCONCELOS; COSTA, 2005).

Os homens seguem sendo as vítimas mais frequentes de homicídio. Em 2005, eles representavam $91,9 \%$ das vítimas. Esse percentual tem variado muito pouco, posto que em 2015 92,2\% das vítimas seguiam sendo do sexo masculino. $\mathrm{O}$ mesmo pode ser dito do perfil etário. Em 2005, cerca de 55,7\% das vítimas eram jovens entre 15 e 29 anos. Em 2015 , os jovens respondiam por $52,9 \%$ das mortes violentas.

As variaçôes nas taxas de homicídio entre grupos de cores diferentes têm sido exploradas por alguns estudos (MINAYO, 1994; SOARES, 2008; WAISELFISZ, 2004). Em 2015 , cerca de $71 \%$ das vítimas eram pessoas negras. De acordo com o Instituto de Pesquisa Econômica Aplicada (Ipea), o cidadão negro tem chances $23,5 \%$ maiores de sofrer assassinato em relação a cidadãos de outras cores, já descontado o efeito da idade, sexo, escolaridade, estado civil e bairro de residência (CERQUEIRA; COELHO, 2017). Em 2005, a taxa de homicídios das pessoas negras era de 31,8 por 100 mil habitantes. Esse número aumentou para 37,7 em 2015.

A arma de fogo é o principal instrumento utilizado para causar mortes violentas. Em 2005, 69,4\% dos homicídios foram cometidos com armas de fogo. O percentual segue praticamente inalterado. Em 2015, as armas de fogo causaram 70,9\% dos homicídios. O percentual é alto se comparado com outros lugares. Na Europa, por exemplo, apenas 21\% são causados por armas de fogo.

Estudos sugerem que a simples presença de armas de fogo não produz necessariamente altas taxas de letalidade. Entretanto, no caso brasileiro, devido a diversas idiossincrasias, a presença de armas aumenta, sim, o grau de letalidade em conflitos interpessoais, atuando, assim, diretamente sobre as taxas de violência (MARINHO; ANDRADE, 2011). Segundo Phebo (2005), o Brasil foi, em 2002, o país com maior número de mortes causadas por armas de fogo no mundo (38.088 casos).

Estudos têm demonstrado relação entre o aumento do número de armas de fogo em circulação e o crescimento dos homicídios (SOARES, 2008). Cerqueira e Mello (2014) mostraram evidências de que cada $1 \%$ no aumento da proliferação de armas de fogo faz com que a taxa de homicídio aumente em torno de $2 \%$ nas cidades. Isso acontece por três razóes. Em primeiro lugar, a maior disponibilidade de armas faz diminuir o seu preço no mercado ilegal, permitindo o acesso a ela do criminoso desorganizado (muitas vezes aquele criminoso que, ao praticar um roubo, termina cometendo latrocínio). Em segundo, as chances de um indivíduo armado sofrer homicídio, ao ser abordado por criminosos, aumenta. Por último, muitos crimes letais (seja feminicídios, brigas de bar, de trânsito, entre vizinhos etc.) acontecem num ambiente de conflito, em que o portador de uma arma de fogo se descontrola e mata o oponente.

Mais recentemente, alguns estudos passaram a explorar os aspectos ecológicos, relacionados ao lugar de moradia das vítimas. Em vez de municípios, esses estudos passaram a tomar os bairros como unidade de análise (RAMÃO; WADI, 2010; SANTOS et al., 2001). A partir de análises georreferenciadas verificou-se que, em geral, poucos bairros concentram a maior parte dos homicídios registrados nos municípios. Esse padrão evidencia a relaçáo dos homicídios com processos de urbanizaçáo desordenada, segregação espacial, exclusão social e dinâmicas de sociabilidade violenta que se consolidaram em algumas localidades (ZILLI; BEATO, 2015). Não são apenas os homicídios que apresentam alta concentraçáo espacial. Rivero (2010) mostrou a existência de padróes de distribuição das mortes decorrentes 
da ação policial. No Rio de Janeiro, os autos de resistência se concentram em alguns lugares, aumentando a segregação social das populaçóes das favelas mais populosas e dos bairros mais pobres.

Algumas pesquisas mostram o crescimento vertiginoso de um tipo bastante específico de homicídio, que envolve (como vítimas e autores) grupos de jovens negros ou pardos, pobres, com baixo nível de educação formal, moradores de favelas, envolvidos em conflitos armados (BEATO; ZILLI, 2012; SAPORI; SENA; SILVA, 2012). Os estudos mostram que o fenômeno das gangues deve ser analisado a partir do seu grau de estruturação e dos diferentes estágios de organização dos grupos (ZILLI; BEATO, 2015).

Outros estudos, tomando por base o município do Rio de Janeiro, buscaram entender como as facçôes interagem a partir de redes geograficamente definidas fundamentadas nas relações de reciprocidade horizontal. Assim, quando uma facçáo fica sem drogas ou armas, pode obtê-las em favelas amigas. Além disso, teve início uma corrida armamentista com o objetivo de dissuadir os rivais de entrar em guerra devido ao número de soldados ou de armas exibido pela quadrilha ou comando (CECCHETTO, 2004, ZALUAR; MONTEIRO, 2013).

A dificuldade de entender a dinâmica dos homicídios não se refere apenas a fragilidades das teorias utilizadas. Deve-se também à precariedade das informaçóes sobre o fenômeno. $\mathrm{Na}$ verdade, até agora nos contentamos em "contar as mortes", como sugeriu Alba Zaluar (1999). Os registros sobre as mortes violentas se limitam a apontar o número de homicídios, o lugar onde os crimes ocorreram, o sexo e a idade das vítimas. Não há estatísticas confiáveis sobre as motivaçóes das mortes, tampouco a respeito das situaçôes em que elas aconteceram. Pouco se sabe sobre a relação entre vítimas e agressores.
Os dados existentes sobre homicídios refletem as consequências de uma variedade de situações e conflitos cujo resultado é a morte de alguém. Portanto, a leitura das estatísticas não pode dar lugar à ideia simplificadora de reduzir o fenômeno dos homicídios a uma única situação. Os homicídios abrangem uma série de comportamentos sociais cujas explicaçôes repousam em diferentes dinâmicas e motivaçôes.

De certa forma, a fragilidade das estatísticas oficiais sobre os homicídios tem sido minorada pelos estudos qualitativos desenvolvidos pelos pesquisadores do tema. As pesquisas apontam que as seguintes situaçôes estão fortemente associadas a essas mortes: (1) atividades das gangues, (2) disputas relacionadas ao negócio das drogas, (3) atuação de grupos de extermínio, e (4) mortes decorrentes de conflitos cotidianos. Esses estudos, entretanto, precisam ser complementados por pesquisas quantitativas capazes de comparar o fenômeno entre estados e regióes brasileiras.

Além das características morfológicas e contextuais dos homicídios, só mais recentemente iniciou-se um debate sobre o que significa registrar o ato de matar no Brasil. Isso porque, quando se toma apenas os dados do sistema de saúde, pouco avançamos na compreensão das dinâmicas criminais e/ou das respostas públicas ao crime, à violência eà demanda por direitos. Ao longo das duas últimas décadas, os dados do sistema de saúde eram tomados como tradução do número mais próximo do real de mortalidade violenta no país. Contudo, a partir da criação da categoria "mortes violentas intencionais” pelo Fórum Brasileiro de Segurança Pública (FBSP), que passou a publicar em seu anuário todas as principais ocorrências e tipos criminais resultando em morte sob essa categoria, pode-se perceber a diferença entre os dados do Ministério da Saúde e os dados que não eram contabilizados pelas polícias na categoria de homicídios das mortes decorrentes 
de intervenção policial. As pesquisas acadêmicas tiveram que investir na produção própria de dados, na medida em que o sistema de justiça criminal e de segurança pública opera formalmente com um número menor de casos letais não por questôes meramente metodológicas, mas por opçóes político-institucionais.

E se durante muito tempo o debate sobre práticas institucionais foi baseado em dados e evidências produzidos diretamente pela universidade, algumas de suas principais questóes foram tomando forma só mais recentemente, em especial a partir da ação de algumas entidades públicas e da sociedade civil, como a Coordenadoria de Análise e Planejamento da Secretaria de Segurança Pública de São Paulo, o Instituto de Segurança do Rio de Janeiro e o FBSP. Hoje há consenso sobre a necessidade de trabalhar o fenômeno das "mortes decorrentes de intervenção policial" conjuntamente à quantidade de "mortes de policiais" e como faces de um mesmo processo social. Antes da ação institucional do FBSP em compilar dados, por força de pedidos de Lei de Acesso à Informação, o debate sobre mortes decorrentes de intervenção policial e mortes de policiais eram mobilizadas de forma muito antagônica, de acordo com posiçôes político-ideológicas de cada lado da discussão. Foi apenas a partir de 2013 que dados nacionais foram compilados e publicados e deslocaram as análises para um contexto nacional como um todo - antes elas ficavam concentradas na região Sudeste do país, com maior tradição de produção e uso de estatísticas.

\section{Vitimização, confiança e medo}

As estatísticas criminais, produzidas a partir dos registros policiais, embora sejam importantes, náo contemplam todos os problemas relacionados à segurança pública. De certa forma, elas focam em crimes e criminosos, revelando muito pouco sobre a percepção dos cidadãos. Assim, para superar essa lacuna surgiram as pesquisas de vitimização. Elas consistem na realização de um survey numa amostra populacional para medir, em geral, três aspectos: vitimização, confiança nas instituiçóes (especialmente nas polícias) e medo do crime.

As primeiras pesquisas surgiram nos EUA na década de 1960, sendo logo difundidas para diversos países europeus, como Inglaterra, França e Noruega. No Brasil, são raras as pesquisas governamentais sobre o tema. Em 1988, o Instituto Brasileiro de Geografia e Estatística introduziu pela primeira vez na sua Pesquisa Nacional por Amostragem Domiciliar um questionário sobre vitimização. Em 2010, o Ministério da Justiça contratou o Instituto Datafolha para realizar a primeira pesquisa nacional de vitimização. Até o momento, esses são os dois únicos levantamentos nacionais.

Assim, ao longo dos últimos 20 anos surgiram algumas pesquisas de abrangência local e sem periodicidade em São Paulo, Rio de Janeiro e Belo Horizonte. Elas foram realizadas devido ao esforço de universidades e instituiçóes da sociedade civil, como Universidade de Sáo Paulo, Universidade Federal de Minas Gerais, Universidade do Estado do Rio de Janeiro, Instituto Latino-Americano das Naçóes Unidas para Prevenção do Delito e Tratamento do Delinquente, Instituto de Estudos da Religião e Fundação Seade. O universo das amostras variou. Algumas pesquisas se limitaram às capitais, outras abrangeram regióes metropolitanas ou estados. Foram raras as pesquisas realizadas em municípios do interior (CRUZ; AZEVEDO; GONÇALVES, 2011). Algumas se basearam em amostragens domiciliares e outras utilizaram o método de cotas. $\mathrm{O}$ período de referência também variou. Enquanto algumas pesquisas perguntaram se o entrevistado fora vítima de crime nos últimos 12 meses, outras utilizaram cinco anos como período de referência. De qualquer forma, é com base nesses estudos que os pesquisadores 
tentaram entender melhor os fenômenos associados à vitimização.

Algumas pesquisas se concentraram em desvendar o tamanho das cifras ocultas, ou seja, a proporçáo de eventos criminais que náo foram comunicados às polícias. A subnotificação varia de acordo com o tipo de crime, o bairro e o perfil das vítimas. Entretanto, quando se trata de violência doméstica, até mesmo os tradicionais modelos de pesquisas de vitimização encontram dificuldades para aferir o fenômeno.

Ainda sobre vitimização, algumas pesquisas buscaram descrever os principais fatores associados ao fenômeno. Em geral, os homens e os jovens são as vítimas mais frequentes dos crimes. Além do perfil das vítimas, os fatores ambientais também têm forte impacto nas chances de alguém ser vítima de determinados crimes. Beato, Peixoto e Andrade (2004) mostraram que os trabalhadores que usam frequentemente transporte público têm maior probabilidade de serem furtados, pois frequentam mais lugares públicos e têm mais contato com pessoas desconhecidas. Já nos casos de roubos (tentados e consumados), além da exposição em transporte público, o gênero e a proximidade com o agressor têm forte associação com a vitimização. Com relação às agressóes, os autores sugerem que os jovens têm maiores chances de vitimização, pois tendem a ter maior exposição a fatores ambientais como bares e boates. Analisando outros tipos de crime, Madalozzo e Furtado (2011) chegaram a conclusóes parecidas. As autoras apontaram que os fatores ambientais, relacionados ao estilo de vida, afetam as chances de alguém ser vítima dos crimes de agressão e roubos e furtos de residência e carros.

Alguns grupos sociais tendem a ter maiores taxas de vitimização, como é o caso dos policiais. Minayo, Souza e Constantino (2007), utilizando dados de uma pesquisa de qualidade de vida, verificaram altas taxas de vitimização entre os policiais do Rio de Janeiro. Durante e Oliveira Junior (2013) chegaram a resultados convergentes a partir de uma amostra nacional. Os autores verificaram que $27 \%$ dos policiais matriculados nos cursos de ensino a distância do Ministério da Justiça haviam sido vítimas de violência física e $5 \%$ já tinham sido baleados. Segundo os autores, gênero, idade, renda e tempo de serviço têm forte impacto nesse tipo de vitimização. Boa parte dos policiais já foram ameaçados (46\%), discriminados (66\%), ou sofreram algum tipo de assédio no ambiente de trabalho (61\%). Para os autores, a renda, a área de atuação e a cor são fatores preditivos para vitimização desse tipo de crime.

Os resultados são coerentes com os achados de Constantino, Ribeiro e Correa (2013). Para as autoras, a área de atuação tem impacto significativo na vitimização policial. No estado do Rio de Janeiro, 67,8\% dos policiais da capital, 13,7\% da Baixada Fluminense e $9,7 \%$ do interior foram vitimados. Os policiais da capital estáo mais expostos ao risco de confronto com a criminalidade e são menos valorizados pela população, mas, por outro lado, nessa área existe maior apoio operacional da corporação.

Outro aspecto mensurado nas pesquisas de vitimização é a confiança da população nas polícias. Afinal, sem confiança, é pouco provável que a população colabore com a polícia, fornecendo informaçóes sobre as atividades criminosas. Oliveira Junior e Alencar (2015) sugerem que uma percepção negativa tem efeito significativo sobre a tendência de optar por náo procurar a polícia quando ocorre um crime. A partir de uma amostra nacional, os autores verificaram que cerca de $28 \%$ das vítimas de roubos ou furtos não registraram o crime na polícia e outros $21 \%$ só procuram a polícia pela necessidade legal do $\mathrm{BO}$.

É preciso, entretanto, diferenciar a confiança na polícia da satisfação com os serviços prestados por ela. Afinal, podemos confiar nas 
polícias e não estarmos satisfeitos com seus serviços. Além disso, pode haver percepçóes distintas sobre a qualidade da atuação da polícia entre aqueles que tiveram contato com policiais e aqueles que não tiveram.

Oliveira Junior (2011) avaliou a satisfação da população quanto ao desempenho das polícias. A partir de uma amostra nacional, o autor verificou que os entrevistados tendem a avaliar negativamente o trabalho policial. Entretanto, as pessoas que já acionaram a polícia avaliaram o atendimento de forma bem mais positiva. Entre as pessoas que já tiveram contato como a polícia, a chance de uma boa avaliaçáo do atendimento realizado por policiais diminui significativamente quando a cor do entrevistado não é branca.

Ainda segundo o autor, a confiança nas instituiçóes policiais é, em boa medida, explicada pela avaliação do desempenho das polícias, especialmente a avaliação difusa. $\mathrm{O}$ fato de haver um atendimento anterior mal avaliado tem efeito negativo significativo sobre a confiança. Ou seja, náo somente a percepção geral do desempenho das instituiçóes policiais influencia o grau de confiança, como também a percepção sobre o desempenho de policiais em situaçôes específicas.

Há uma série de fatores que influenciam a imagem difusa que a população faz das polícias. Gélison Silva e Cláudio Beato Filho (2013) apontam que a confiança na polícia está correlacionada à confiança na justiça. É provável que exista confusão entre as funçóes do trabalho policial e do sistema de justiça criminal. Os autores observaram também alta correlação entre a confiança na polícia e nos governos, especialmente federal e estadual, pois é impossível analisar a confiança na polícia em separado da confiança nos governos. Esses resultados são coerentes com os achados de Bráulio Silva e Claudio Beato Filho (2013), para quem a desconfiança na polícia é explicada principalmente pelos déficits institucionais percebidos pela população.
O medo do crime é outro aspecto avaliado nas pesquisas de vitimização. Criminalidade e medo do crime são fenômenos autônomos. Embora possa existir algum grau de correlação (dependendo do grupo social, do tipo de crime e do lugar), eles têm dinâmicas próprias, causas e consequências distintas. $\mathrm{O}$ medo do crime não é simplesmente o resultado da criminalidade ou das imagens e notícias produzidas pela mídia. Ele diz respeito a sentimentos difusos de ansiedades e incertezas que sáo resultado das transformaçôes sociais das sociedades pós-modernas.

De forma geral, a literatura sobre o medo do crime tem buscado explicar o fenômeno a partir de duas perspectivas. A primeira enfatiza aspectos que aumentam o medo, tais como vulnerabilidades físicas, sociais, desordens e desorganização social. A segunda perspectiva se concentra na análise dos aspectos que reduzem o medo: laços sociais, vínculos comunitários, coesão social e eficácia coletiva.

No Brasil, ainda sáo raros os estudos que buscam entender o medo do crime. Pesquisas sugerem que as pessoas se sentem mais seguras em locais conhecidos e próximos de suas residências (BORGES, 2011; DAVIS; PEIXOTO, 2003). Bráulio Silva e Beato Filho (2013) verificaram associação positiva entre as mulheres e os mais velhos com o medo de crime. No nível da vizinhança, o principal resultado foi que a coesão social afeta a associação entre a taxa de criminalidade e o medo do crime. Borges (2015) aponta que a relação entre a vitimização e o medo do crime depende do tipo de crime. As pessoas vítimas de roubo se sentem mais inseguras do que aquelas que foram vítimas de furto.

Apesar dos esforços realizados por alguns pesquisadores, é muito difícil comparar essas pesquisas entre si, uma vez que as variáveis selecionadas nem sempre foram as mesmas. Além disso, existem diferenças metodológicas significativas em relação ao desenho da amostra, ao período de referência adotado e ao público-alvo 
de cada uma dessas pesquisas. Na verdade, a falta de pesquisas nacionais e regulares de vitimização torna praticamente impossível entender a real dimensão da criminalidade, da confiança nas polícias e do medo do crime no Brasil. O atual quadro social brasileiro indica a urgência de se realizar pesquisas de vitimização periódicas e abrangentes, uma vez que elas são importantes instrumentos para o planejamento das polícias públicas de segurança.

\section{Analisando o fluxo da justiça criminal}

Não basta saber quantos crimes aconteceram, também é necessário entender como esses crimes são processados pelo sistema de justiça criminal. A despeito da importância do tema, o Brasil não dispóe ainda de um sistema de estatísticas processuais que permita aos pesquisadores entender quais são os principais problemas do sistema de justiça criminal. Para contornar essas dificuldades, surgiram algumas pesquisas exploratórias visando analisar as formas e dinâmicas com as quais o sistema processa as ocorrências criminais. As pesquisas de fluxo de justiça, como são conhecidas, têm sido cada vez mais frequentes.

Até o momento, não foi possível reconstruir os fluxos de justiça com base nas estatísticas oficiais. Essa dificuldade tem impactado profundamente os estudos sobre o tema, fazendo com que os pesquisadores se esforçassem para produzir bases de dados sobre fluxo para depois interpretá-las. Misse e Vargas (2007) identificaram três abordagens diferentes utilizadas para produçáo dessas bases. A primeira, longitudinal, destina-se a acompanhar os processos a partir dos registros policiais, seguindo-os até a execução da sentença. A base não precisa necessariamente conter todas as etapas decisórias do fluxo de justiça, podendo se concentrar apenas em alguns aspectos. A segunda abordagem, identificada pelos autores como transversal, busca construir bases de dados utilizando estatísticas obtidas de diferentes organizaçóes (Polícia Civil, Ministério Público, Tribunal de Justiça), sem o acompanhamento do percurso de pessoas e papéis por elas. Finalmente, a terceira e mais frequente abordagem utilizada, longitudinal retrospectiva, visa construir bases de dados do final para o início do processo de incriminação. Para tanto, elege-se uma fase como ponto de partida (em geral o arquivamento final) e levantam-se os dados contidos nos processos.

Os autores salientam ainda que as abordagens transversal e longitudinal retrospectiva "não permitem recuperar as perdas ocorridas ao longo do processamento, pois estáo excluídos os casos que foram arquivados" (MISSE; VARGAS, 2007, p. 8). Já a abordagem longitudinal para montagem da base de dados demanda capacidade de acompanhar as diferentes fases do fluxo de justiça, o que é muito difícil, posto que as organizaçóes registram seus respectivos inquéritos, denúncias e processos com numeração diferente. Porém, vale destacar, apesar de todas as dificuldades, o uso dessas diferentes abordagens para reconstruir a sequência do fluxo de justiça faz parte dos esforços dos pesquisadores para preencher uma importante lacuna na produção das estatísticas oficiais brasileiras.

Entre os estudos sobre fluxo de justiça, destacam-se as pesquisas que objetivaram compreender o processamento dos crimes de homicídio. Partindo de diferentes fontes e valendo-se de metodologias variadas, Soares (1996), Cano (2005b), Misse e Vargas (2007) e Ribeiro e Duarte (2009) analisaram o fluxo de justiça dos homicídios no Rio de Janeiro. Também foram realizadas pesquisas em São Paulo; ${ }^{4}$ Campinas (VARGAS; BLAVATSKY; RIBEIRO, 2005), Brasília (COSTA, 2015;

4 Disponível em: <http://produtos.seade.gov.br/projetos/acervossp>. Acesso em: 13 abr. 2018. 
COSTA; ZACKSESKI; MACIEL, 2016), Florianópolis (RIFIOTIS, 2006; RUSCHEL, 2006), Belo Horizonte (BATITUCCI; CRUZ, 2006; SAPORI, 2007) e Recife (RATTON; FERNANDES, 2007).

Apesar das diferenças metodológicas, os estudos sobre o fluxo do crime de homicídios revelam que poucos casos são denunciados pelo Ministério Público e apenas um reduzido número de réus recebe uma sentença judicial. $\mathrm{O}$ maior gargalo está na investigação dos crimes de homicídio. Entretanto, dada a ausência de estatísticas oficiais sobre a investigação criminal, pouco se sabe sobre quais situaçôes, conflitos e agressores tendem a ter tramitação mais rápida e efetiva.

No Brasil, ainda não é possível determinar quantos homicídios foram esclarecidos, uma vez que não existe um sistema de indicadores que permita mensurar o desempenho da investigação criminal com segurança. As pesquisas têm apontado um fraco desempenho das polícias brasileiras no esclarecimento dos crimes de homicídios (COSTA, 2015). Embora utilizem metodologia e critérios distintos, esses estudos sugerem que o desempenho das polícias civis brasileiras varia bastante. Em alguns estados, o número de casos denunciados pelo Ministério Público é inferior a 10\%. Em 2002, por exemplo, alguns países apresentaram taxas de esclarecimento de homicídios elevadas, como Alemanha (96\%), Japão (95\%), e Inglaterra (81\%), Canadá (80\%) e EUA (64\%). ${ }^{5}$

As pesquisas não se resumiram ao estudo do processamento de homicídios. Algumas pesquisas se concentraram em entender $o$ fluxo de justiça de outros tipos de crimes, como estupro (VARGAS, 2007), violência contra mulher (IZUMINO, 1998; ABDALA;
SILVEIRA; MINAYO, 2011), tortura (JESUS, 2010), autos de resistência (MISSE; GRILLO; NETI, 2015) e linchamentos (ADORNO; IZUMINO, 2007; PINHEIRO; ADORNO; CARDIA, 1999). Outras pesquisas analisaram o fluxo de justiça dos casos encaminhados para os Juizados Especiais Criminais (BATITUCCI et al., 2010; RIBEIRO, 2009).

De forma geral, esses estudos buscaram analisar os principais gargalos entre o registro das ocorrências criminais, as denúncias e as sentenças judiciais. Após uma década de estudos, verificou-se que cada crime tem seu próprio fluxo de justiça. Isso não acontece apenas por causa das especificidades da legislação penal e processual penal, mas também devido às prioridades que os profissionais do sistema de justiça (policiais, promotores e juízes) conferem a cada evento criminal. A despeito da abrangência nacional da legislação penal e processual penal, constataram-se variaçōes significativas na forma com que os estados processam o mesmo tipo de crime. Ou seja, os diferentes arranjos organizacionais também impactam o fluxo de justiça criminal. Além dos aspectos organizacionais, verificou-se que o tipo de crime, o sexo e a cor das vítimas importam para entender o fluxo de justiça. A existência ou não de flagrante também é fator essencial para entender a tramitação desses casos.

Alguns desses estudos analisaram os tempos de tramitação dos processos no sistema de justiça criminal em São Paulo (ADORNO; IZUMINO, 2007), Rio de Janeiro (RIBEIRO, 2009), Belo Horizonte (BATITUCCI; CRUZ, 2006), Florianópolis (RUSCHEL, 2006), Recife (RATTON; FERNANDES, 2007) e Campinas (VARGAS; BLAVATSKY; RIBEIRO, 2005). De forma geral, essas pesquisas compararam os tempos de processamento

5 Dados retirados do Source book of Criminal Justice Statistics (EUA); Police Crime Statistics (Alemanha); White Paper on Crime (Japão); Crime in England and Wales (Inglaterra) e Canadian Homicide Survey (Canadá). Ver também, Instituto Sou da Paz (2017). 
dos processos judiciais nas diferentes instituiçóes que compóem o sistema de justiça criminal.

Apesar da variedade de fontes e metodologias, de forma geral os estudos sobre o fluxo de justiça têm analisado o funcionamento do sistema de justiça criminal brasileiro com foco principal na sua eficiência. Ou seja, as atençóes têm se concentrado em avaliar a capacidade do sistema de processar adequadamente toda a demanda por puniçáo. O problema é definir o que é "adequado" em termos de fluxo de justiça. Qual é o tempo ideal de justiça? É possível processar todos os crimes?

Numa perspectiva empírica, o tempo "ideal" de justiça pode ser medido a partir da diferença entre o tempo calculado nas pesquisas e os prazos estabelecidos pela legislação. Além disso, é necessário acrescentar os tempos que as instituiçóes levam para processar certos feitos judiciais, tais como cartas precatórias, citaçôes, mandados de prisão e laudos periciais (RIBEIRO; DUARTE, 2009). Mas vale lembrar que não são os problemas da pesquisa empírica que impedem os pesquisadores de chegar a uma definiçáo sobre o funcionamento "adequado" do sistema de justiça criminal. A questão não é empírica, mas teórica. $\mathrm{O}$ que implica debater qual é a função da punição (e do sistema de justiça criminal) no controle das condutas nas sociedades contemporâneas? A resposta deve ser buscada nos livros de teoria social, e não nos manuais de metodologia.

Emile Durkheim certamente é um dos autores que podem iluminar este debate. $\mathrm{O}$ caráter distintivo da sua teoria da punição está na funçáo que ele atribui à pena. Em vez de tomá-la pelo seu aspecto instrumental, como muitos outros o fazem, Durkheim (1999) enfatiza o caráter moral da punição. Para ele, a punição é antes de tudo um processo moral e, por que não dizer, político. A punição não é tomada como instrumento de controle social, mas como mecanismo de governança das vontades. Muito mais do que sua dimensão criminal,
Durkheim (1999) enfatiza seus aspectos morais e políticos. As dificuldades de punir os crimes minam a força da "estrutura moral" e levam à sua "desmoralização". Noutras palavras, a impunidade corrói a soberania e a autoridade de uma ordem legal, e enfraquece os poderes que a suportam. Portanto, a punição não é apenas um instrumento de controle da criminalidade, mas sim, e principalmente, um mecanismo simbólico de reafirmação da ordem política.

Se analisarmos o sistema de justiça criminal pelo seu aspecto simbólico, como Durkheim sugere, precisamos debater sua efetividade. $\mathrm{Ou}$ seja, a forma que o sistema de justiça criminal processa não todas as ocorrências, mas apenas aquelas que foram selecionadas pelos policiais e promotores. Para fazer isso, é preciso ir além das denúncias de seletividade do sistema e passar a debater também sua discricionariedade. Se há discricionariedade no sistema (e é inevitável que haja), precisamos analisar seus critérios, problemas e limites (COSTA, 2015).

Outro problema dos estudos sobre fluxo de justiça é o caráter exploratório das pesquisas. Dada a falta de estatísticas oficiais, os pesquisadores se viram obrigados a produzir seus dados primários, e para isso conduziram pesquisas, via de regra, locais, com pouca comparabilidade nacional e internacional. Assim, deixa-se de analisar os aspectos organizacionais que impactam o funcionamento das polícias, ministério público e judiciário. Essas limitações também têm impedido os pesquisadores de analisar as diferentes formas como as instituiçóes interpretam a lei e seu impacto no funcionamento do sistema.

Essas dificuldades, entretanto, podem ser superadas. Em 16 de dezembro de 2008 foi promulgada a Resolução no 65 do Conselho Nacional de Justiça, que trata da padronizaçáo do número dos processos no âmbito do Judiciário (BRASIL, 2009). A padronização estabelece numeração única que deverá ser utilizada por todos os tribunais, facilitando a 
comunicação entre os órgãos do Judiciário e melhorando o acompanhamento dos processos.

A primeira pesquisa nacional de fluxo de justiça foi realizada pelo Ipea (2015). Com base na numeração única, foi possível realizar um levantamento amostral de todos os processos criminais com baixa definitiva em 2011 nas seguintes UF: Alagoas (AL), Distrito Federal (DF), Espírito Santo (ES), Minas Gerais (MG), Pará (PA), Paraná (PR), Pernambuco (PE), Rio de Janeiro (RJ) e São Paulo (SP). Foi realizada uma amostra de autos findos representativa e significativa para cada UF envolvida no estudo, com intervalo de confiança de $95 \%$ e margem de erro de $2,5 \%$, o que resultou em um quantitativo aproximado de quatrocentos processos criminais por UF, sorteados aleatoriamente entre os componentes do universo.

$\mathrm{O}$ padrão que emerge dos dados da pesquisa nesses nove estados brasileiros difere significativamente das representações tradicionais sobre o funcionamento do sistema de justiça criminal, especialmente do trabalho das polícias civis estaduais. As prisóes em flagrante ocupam lugar de destaque na instrução criminal e têm efeitos significativos nas sentenças. Verificou-se que 57,6\% dos processos criminais analisados foram iniciados por prisão em flagrante dos suspeitos. Além disso, em 6,8\% dos casos os acusados já se encontravam presos por motivos alheios ao processo. Ou seja, em $64,4 \%$ dos casos válidos em análise os acusados já se encontravam presos no momento da instauração dos inquéritos policiais (COSTA; OLIVEIRA JUNIOR, 2016).

\section{Avaliando as políticas públicas de segurança}

Um dos maiores desafios da área é a avaliação das políticas públicas de segurança e das estratégias de policiamento, pois, além da implementação de novos programas, há diversos outros aspectos que afetam as taxas criminais e a sensação de segurança. Mudanças demográficas, econômicas e novas dinâmicas sociais podem afetar as taxas criminais, bem como a emergência de novos padróes educacionais, empregatícios e de saúde. As dificuldades de avaliação também estão presentes em outras áreas (i.e., saúde, educação, mobilidade), mas na área de segurança pública elas ganham maior complexidade devido à existência de efeitos em médio e longo prazos, às limitaçóes das fontes e ao deslocamento da atividade criminal da área de intervenção para outros locais (CANO, 2005a).

De forma geral, as avaliaçóes que enfatizam critérios de validação interna tendem a ser mais consistentes do que aquelas que buscam simplesmente estabelecer relaçóes de causa e efeito. Um processo adequado de avaliação exige duas características dos instrumentos de medida: validade e confiabilidade. Garantir a validade do instrumento significa provar estatisticamente que o questionário realmente mede aquilo a que se propóe, e a confiabilidade pode ser definida como a reprodutibilidade da medida.

A fragilidade tanto das estatísticas criminais quanto dos instrumentos de medida tem sido o maior obstáculo à realização de avaliaçóes mais consistentes das políticas de segurança. Para superá-las, algumas pesquisas têm se baseado em experimentos randomizados, nos quais grupos ou áreas são escolhidos aleatoriamente para tratamento, controle e comparação.

Utilizando um modelo econométrico de diferenças em diferenças, Cerqueira et al. (2015) avaliaram os efeitos da Lei Maria da Penha sobre os homicídios de mulheres. Para isso, compararam as mortes violentas de mulheres ocorridas nas residências com as mortes de homens na mesma situaçấo. $O$ estudo indicou que a lei cumpriu um papel relevante para conter a violência de gênero, ainda que sua efetividade não tenha se dado de maneira uniforme no país.

Outras pesquisas "quase-experimentais" também têm sido empregadas para avaliar políticas de segurança. Essas pesquisas comparam 
determinado grupo (ou área) com outro grupo-controle, mas sem escolha aleatória. Os resultados são robustos e sugerem a necessidade de aprofundar as avaliaçóes, utilizando novos instrumentos e grupos-controle.

Este é o caso dos estudos que tentam relacionar a queda de homicídios ao aumento do aprisionamento de determinados grupos, especialmente dos chamados "homicidas contumazes". Apesar de os estudos não serem conclusivos quanto à correlação entre o aumento do número geral de prisóes e a redução dos homicídios (NADANOVSKY, 2009; NÓBREGA JUNIOR, 2011), o quadro se altera significativamente quando as prisóes se concentram em grupos específicos.

Kahn e Zanetic (2009) verificaram correlação significativa entre o aprisionamento desses homicidas contumazes e a redução das taxas de homicídio. $\mathrm{O}$ mesmo foi verificado por Zaverucha e Nóbrega Junior (2015) ao avaliar os efeitos do programa Pacto pela Vida na reduçáo dos homicídios em Pernambuco. Os autores verificaram correlação entre as prisóes de homicidas e a redução dos homicídios, sendo que as prisóes por homicídio qualificado tiveram efeitos mais significativos do que as prisóes por homicídio simples. Ou seja, as taxas de aprisionamentos só apresentam correlação significativa com a redução dos homicídios se forem concentradas no grupo de homicidas, especialmente no de homicidas seriados.

Silveira et al. (2010) também realizaram um estudo quase-experimental para avaliar os resultados do Programa Fica Vivo na comunidade do Morro das Pedras, em Belo Horizonte. Para isso, compararam estatísticas criminais dessa comunidade com as de outras comunidades e bairros da cidade em três diferentes momentos. $\mathrm{O}$ estudo aponta para uma significativa redução dos homicídios associada à implantação do programa.

Nem sempre é possível realizar estudos randomizados ou quase-experimentais. Assim, algumas pesquisas têm utilizado séries temporais para contrastar o antes e o depois da implantação de uma política de segurança. Como não há validação de instrumentos e tampouco grupo-controle, esses estudos são pouco conclusivos e servem para indicar a necessidade de entender melhor as mudanças em curso.

Esse é o caso do estudo de Barreira e Russo (2012), cujo objetivo era discutir a implantação do Programa Ronda do Quarteirão no estado do Ceará e analisar a recepção por parte dos meios de comunicação e seus efeitos nas taxas de criminalidade e violência. Após a implantação do programa em 2007, segundo os dados da Secretaria de Segurança Pública do Ceará, houve significativa redução no número de roubos e furtos. Seguindo a mesma estratégia, Misse (2014) buscou avaliar os impactos das Unidades de Polícia Pacificadora (UPP) nas estatísticas criminais do Rio de Janeiro. Após a implantação do programa, o autor verificou significativa redução no número de homicídios dolosos, autos de resistência e desaparecimentos nas comunidades onde foram inseridas as 17 primeiras UPP.

Dada a precariedade das estatísticas oficiais e dos indicadores de desempenho, alguns pesquisadores utilizaram diferentes técnicas de pesquisa, como o caso da avaliação realizada pelo Laboratório de Análise da Violência da Universidade do Estado do Rio de Janeiro e pelo FBSP sobre as UPP (CANO, 2012). Para complementar as estatísticas oficiais, os pesquisadores realizaram surveys, entrevistas e georreferenciamento de homicídios. Os resultados da avaliação mostraram que as UPP mudaram, mesmo que de forma incipiente, a relação da polícia com a comunidade. Diminuíram as mortes violentas, e em menor medida os roubos, tanto nas áreas das UPP quanto nas suas adjacências. Por fim, a despeito dos resultados positivos, as UPP gozavam de baixa legitimidade entre os policiais.

Apesar da variedade de estratégias e metodologia de avaliação, ainda são poucos os 
estudos destinados a analisar os efeitos das políticas públicas de segurança. Em parte, isso acontece devido à precariedade das fontes de estatísticas criminais e indicadores de desempenho institucional. No entanto, não há dúvida que precisamos aperfeiçoar as metodologias e os instrumentos de avaliação de políticas públicas de segurança. Só recentemente, com a criação das Áreas Integradas de Segurança Pública em alguns estados, foi possível associar as estatísticas criminais à área de atuação dos batalhóes e delegacias. Isso abre uma enorme possibilidade de avaliação dos projetos-piloto, uma vez que permite comparar seus efeitos com outras áreas não atendidas pela política pública.

\section{Conclusão}

A principal limitação metodológica dos estudos sobre criminalidade e violência no Brasil deve-se à precariedade das estatísticas oficiais produzidas ou sistematizadas no plano federal. É verdade que algumas pesquisas da área apresentam fragilidades teóricas e metodológicas. Para superá-las, entretanto, é necessário realizar estudos comparados para redefinir teorias e reajustar metodologias. Além disso, levantamentos nacionais são caros e demandam esforços governamentais. Em resumo, a falta de estatísticas nacionais tem impedido a comparação e limitado o aperfeiçoamento dos modelos teórico-metodológicos empregados nas pesquisas.

Há uma tendência claramente identificável em alguns países europeus, nos Estados Unidos e no Canadá do aumento da produção de estatísticas oficiais sobre temas relacionados a violência e criminalidade. A melhoria das estatísticas oficiais não impacta apenas a melhoria das pesquisas - afeta também a gestão das políticas públicas, por meio da construção de dados e indicadores que permitam que a segurança pública seja um serviço cuja provisão é baseada intensamente em planejamento, monitoramento e avaliaçáo.
Para a construção de sistemas nacionais de estatísticas oficiais não bastam investimentos em tecnologias e capacitação técnica dos operadores. É necessário, acima de tudo, pactuaçôes políticas para a adoção de sistemas de informaçóes estatísticas, visto que, além da técnica, estatísticas dependem de acordos políticos que definam o que deve ser considerado como prioritário para a intervenção das organizaçóes do sistema de justiça e segurança pública.

Para elaboração de pesquisas mais robustas sobre homicídios, por exemplo, não basta contar os mortos. É preciso produzir dados georreferenciados sobre locais das mortes, perfil das vítimas, relação vítima-agressor, bem como sobre o tipo de conflito e o contexto que ensejou aquela morte. $\mathrm{O}$ mesmo pode ser dito com relação à atuação das polícias. Não basta utilizar apenas categorias penais no $\mathrm{BO}$; devemos acrescentar informaçôes sobre gênero, cor/raça, idade, grupos vulneráveis, entre outras variáveis explicativas para os fenômenos do crime e da violência.

Também sabemos que as estatísticas criminais não esgotam a discussão sobre segurança pública. É necessário realizar levantamentos nacionais capazes de comparar as percepçóes da população sobre a atuação das polícias e o medo do crime entre as unidades da federação, comparando também com dados de outros países. Por fim, a inexistência de um sistema nacional de informaçóes processuais nos impede de entender o funcionamento do sistema de justiça criminal, seus limites e seus critérios decisórios

Não se trata simplesmente de produzir dados, pois o Brasil produz dados estatísticos sobre crimes e criminosos desde o século XIX (LIMA, 2005). Trata-se de construir sistemas de estatísticas nacionais úteis para a realização de pesquisas e diagnósticos, bem como para avaliação de políticas públicas. Sem esses sistemas, as pesquisas na área continuarão limitadas a estudos de caso, com baixa comparabilidade. 


\section{Referências}

ABDALA, C.; SILVEIRA, K.; MINAYO, M. C. S. Aplicaçấo da Lei Maria da Penha nas delegacias de mulheres: o caso do Rio de Janeiro. Dilemas, Rio de Janeiro, v. 4, n. 4, p. 571-600, 2011.

ADORNO, S.; IZUMINO, W. P. Justice in time and the time of justice. Tempo Social, São Paulo, v. 19, n. 2, p. 131-155, 2007.

ANDRADE, L. T.; DINIZ, A. M. A. A reorganização espacial dos homicídios no Brasil e a tese da interiorização. Revista Brasileira de Estudos da População, Rio de Janeiro, v. 30, p. 171-191, 2013. Suplemento 1.

ANDRADE, M. V.; LISBOA, M. B. A violência como causa de mortalidade. Conjuntura Econômica, Rio de Janeiro, v. 54, n. 5, p. 61-64, 2000.

BARREIRA, C.; ADORNO, S. A violência na sociedade brasileira. In: MARTINS, C. B.; MARTINS, H. H. (Orgs.). Horizontes das ciências sociais no Brasil: sociologia. São Paulo: Anpocs, 2010. p. 303-374.

BARREIRA, C.; RUSSO, M. B. O Ronda do Quarteirão: relatos de uma experiência. Revista Brasileira de Segurança Pública, São Paulo, v. 6, n. 2, p. 282-297, 2012.

BATITUCCI, E. C.; CRUZ, M. V. G. Fluxo do crime de homicídio no sistema de justiça criminal de Minas Gerais. In: ENCONTRO ANUAL DA ANPOCS, 30., 2006, Caxambu. Anais... São Paulo: Anpocs, 2006. p. 1-15.

BATITUCCI, E. C. et al. A justiça informal em linha de montagem. Civitas, Porto Alegre, v. 10, n. 2, p. 245-269, 2010.

BEATO FILHO, C. C. Determinantes da criminalidade em Minas Gerais. Revista Brasileira de Ciências Sociais, São Paulo, v. 13, n. 37, p. 74-87, 1998.

Fontes de dados principais em estudos criminológicos: limites e potenciais. In: FÓRUM DE DEBATES CRIMINALIDADE, VIOLÊNCIA E SEGURANÇA PÚBLICA NO BRASIL: UMA DISCUSSÃO SOBRE BASES DE DADOS E QUESTÓES METODOLÓGICAS, 1., 2000, Rio de Janeiro. Anais... Rio de Janeiro: Ipea; Ucam, 2000. p. 88-110.

BEATO FILHO, C. C. et al. Conglomerados de homicídios e o tráfico de drogas em Belo Horizonte, Minas Gerais, Brasil, de 1995 a 1999. Cadernos de Saúde Pública, Rio de Janeiro, v. 17, n. 5, p. 1163-1171, 2001.

BEATO FILHO, C. C.; PEIXOTO, B. T.; ANDRADE, M. V. Crime, oportunidade e vitimização. Revista Brasileira de Ciências Sociais, São Paulo, v. 19, n. 55, p. 73-90, 2004.

BEATO FILHO, C. C.; ZILLI, L. F. A estruturação de atividades criminosas: um estudo de caso. Revista Brasileira de Ciências Sociais, São Paulo, v. 27, n. 80, p. 71-88, 2012.

BORGES, D. O medo do crime na cidade do Rio de Janeiro: uma análise sob a perspectiva das crenças de perigo. Curitiba: Appris, 2011. 
Vitimização e sentimento de insegurança no Brasil em 2010: teoria, análise e contexto. Mediaçōes, Londrina, v. 18, n. 1, p. 141-163, 2015.

BRASIL. Conselho Nacional de Justiça. Resolução no ${ }^{65}$, de 16 de dezembro de 2008. Dispóe sobre a uniformização nos órgãos do Poder Judiciário e dá outras providências. Diário de Justiça Eletrônico, Brasília, DF, 9 jan. 2009. p. 2-27.

CAMPOS, M. S.; ALVAREZ, M. Políticas públicas de segurança, violência e punição no Brasil (2000-2016). In: MICELI, S.; MARTINS, C. B. (Orgs.). Sociologia brasileira hoje. Cotia: Ateliê, 2017. p. 143-216.

CANO, I. Registros criminais da polícia no Rio de Janeiro: problemas de validade e confiabilidade. In: FÓRUM DE DEBATES CRIMINALIDADE, VIOLÊNCIA E SEGURANÇA PÚBLICA NO BRASIL: UMA DISCUSSÃO SOBRE BASES DE DADOS E QUESTÓES METODOLÓGICAS, 1., Rio de Janeiro. Anais... Rio de Janeiro: Ipea; Ucam, 2000. p. 111-121.

Avaliação de programas de intervenção em violência, criminalidade e segurança pública. In: BRITO, D. C.; BARP, W. J. (Orgs.). Violência e controle social: reflexôes sobre políticas de segurança pública. Belém: Edufpa, 2005a. p. 17-30.

. Mensurando a impunidade no sistema de justiça criminal do Rio de Janeiro. Rio de Janeiro: CESeC, 2005b. Relatório de pesquisa.

(Org.). Os donos do morro: uma avaliação exploratória das Unidades de Polícia Pacificadora (UPP’s) no Rio de Janeiro. São Paulo: Fórum Brasileiro de Segurança Pública; Rio de Janeiro: Laboratório de Análise da Violência, 2012.

CANO, I.; SANTOS, N. Violência letal, renda e desigualdade social no Brasil. Rio de Janeiro: 7Letras, 2001.

CANTOR, D.; LYNCH, J. P. Self-report surveys as measures of crime and criminal victimization. In: U. S. DEPARTMENT OF JUSTICE. Measurement and analysis of crime and justice: criminal justice 2000. Washington, DC: National Institute of Justice, 2000. v. 4, p. 85-138.

CECCHETTO, F. Violências e estilos de masculinidade no Rio de Janeiro. Rio de Janeiro: FGV, 2004.

CERQUEIRA, D. R. C.; COELHO, D. Democracia racial e homicídios de jovens negros na Cidade Partida. Brasília, DF: Ipea, 2017.

CERQUeIRA, D. R. C. et al. Avaliando a efetividade da Lei Maria da Penha. Brasília: Ipea, 2015. (Série Texto para Discussão, no 2.048).

CERQUEIRA, D. R. C.; MELLO, J. M. P. Firearms and crime in Brazil. In: BATCHELOR, P.; KENKEL, K. M. (Eds.). Controlling small arms: consolidation, innovation and relevance in research and policy. New York: Routledge, 2014. p. 201-217.

CERQUEIRA, D. R. C.; LOBÃO, W.; CARVALHO, A. O jogo dos sete mitos e a miséria da segurança pública no Brasil. Brasília, DF: Ipea, 2005. 
CONSTANTINO, P.; RIBEIRO, A.; CORREA, B. Percepção do risco entre policiais civis de diferentes territórios do estado do Rio de Janeiro. Ciência e Saúde Coletiva, Rio de Janeiro, v. 18, n. 3, p. 645-655, 2013.

COSTA, A. T. M. A (in)efetividade da justiça criminal brasileira: uma análise do fluxo de justiça dos homicídios no Distrito Federal. Civitas, Porto Alegre, v. 15, n. 1, p. 11-26, 2015.

COSTA, A. T. M.; OLIVEIRA JÚNIOR, A. Novos padróes de investigação policial no Brasil. Sociedade e Estado, Brasília, DF, v. 31, n. 1, p. 147-164, 2016.

COSTA, A. T. M.; ZACKSESKI, C.; MACIEL, W. C. A investigação e o processamento dos crimes de homicídio na Área Metropolitana de Brasília. Revista Brasileira de Segurança Pública, São Paulo, v. 10, n. 1, p. 36-54, 2016.

CRUZ, S. H.; AZEVEDO, M.; GONÇALVES, H. Vitimização por violência urbana em uma cidade de médio porte do sul do Brasil. Revista Brasileira de Epidemiologia, Săo Paulo, v. 14, n. 1, p. 15-26, 2011.

DAVIS, C.; PEIXOTO, B. Medo e espaço urbano: uma análise da percepção do risco de vitimização local e não local. In: CONGRESSO BRASILEIRO DE SOCIOLOGIA, 11., 2003, Campinas. Anais... Campinas: Sociedade Brasileira de Sociologia, 2003. p. 2-26.

DIRK, R. C. Homicídio doloso no estado do Rio de Janeiro: uma análise sobre os registros de ocorrência da polícia civil. 2007. 139 f. Dissertação (Mestrado em Estudos Populacionais e Pesquisa Social) - Escola Nacional de Ciências Estatísticas, Rio de Janeiro, 2007.

DURANTE, M. O.; OLIVEIRA JÚNIOR, A. Vitimização dos policiais militares e civis no Brasil. Revista Brasileira de Segurança Pública, Săo Paulo, v. 7, n. 1, p. 132-150, 2013.

DURKHEIM, E. Da divisão social do trabalho. São Paulo: Martins Fontes, 1999.

INSTITUTO DE PESQUISA ECONÔMICA APLICADA. A aplicação de penas e medidas alternativas. Brasília, DF: Ipea, 2015. (Relatório de pesquisa).

INSTITUTO SOU DA PAZ. Onde mora a impunidade? por que o Brasil precisa de um indicador nacional de esclarecimento de homicídios. São Paulo: Instituto Sou da Paz, 2017. Disponível em: <https://goo.gl/68rDLG>. Acesso em: 13 abr. 2018.

IZUMINO, W. P. Justiça e violência contra a mulher: o papel do sistema judiciário na solução dos conflitos de gênero. São Paulo: Annablume, 1998.

JANNUZZI, P. M. Indicadores sociais no Brasil: conceitos, fontes de dados e aplicaçôes. 6. ed. Campinas: Alínea, 2017.

JESUS, M. G. M. Os julgamentos do crime de tortura: um estudo processual na cidade de São Paulo. Dilemas, Rio de Janeiro, v. 3, n. 9, p. 143-172, 2010.

KAHN, T. Pesquisas de vitimização. Revista do Ilanud, São Paulo, n. 10, 1998. 
Medindo a criminalidade: um panorama dos principais métodos e projetos existentes. In: FÓRUM DE DEBATES CRIMINALIDADE, VIOLÊNCIA E SEGURANÇA PÚBLICA NO BRASIL: UMA DISCUSSÃO SOBRE BASES DE DADOS E QUESTÓES METODOLÓGICAS, 1., 2000, Rio de Janeiro. Anais... Rio de Janeiro: Ipea; Ucam, 2000. p. 59-87.

KAHN, T.; ZANETIC, A. O papel dos municípios na segurança pública. Porto Alegre, Editora UFRGS, 2009.

KANT DE LIMA, R. K.; MISSE, M.; MIRANDA, A. P. Violência, criminalidade, segurança pública e justiça criminal no Brasil: uma bibliografia. Revista Brasileira de Informação Bibliográfica em Ciências Sociais, São Paulo, n. 50, p. 45-123, 2000.

LIMA, R. S. Contando crimes e criminosos em São Paulo: uma sociologia das estatísticas produzidas e utilizadas entre 1871 e 2000. 2005. 205 f. Tese (Doutorado em Sociologia) - Universidade de São Paulo, Sáo Paulo, 2005.

Entre palavras e números: violência, democracia e segurança pública no Brasil. São Paulo: Alameda, 2011.

LIMA, R. S.; BORGES, D. Estatísticas criminais. In: LIMA, R. S.; RATTON, J. L.; AZEVEDO, R. G. (Orgs.). Crime, polícia e justiça no Brasil. São Paulo: Contexto, 2014. p. 213-226.

LIMA, R. S.; PEIXOTO, B. T.; DURANTE, M. O. Metodologias e criminalidade violenta no Brasil. São Paulo em Perspectiva, São Paulo, v. 18, n. 1, p. 13-21, 2004.

LOPES, C. S. Por que os brasileiros desconfiam da polícia? uma análise das causas da desconfiança na instituição policial. In: ENCONTRO DA ASSOCIAÇÃO BRASILEIRA DE CIÊNCIA POLÍTICA, 7., 2010, Recife. Anais... Recife: ABCP, 2010. p. 1-31.

MADALOZZO, R.; FURTADO, G. M. Um estudo sobre a vitimização para a cidade de São Paulo. Revista de Economia Política, São Paulo, v. 31, n. 1, p. 160-180, 2011.

MARINHO, M. A. C.; ANDRADE, L. T. O sobe e desce das taxas de homicídios na Região Metropolitana de Belo Horizonte: armas de fogo, drogas e políticas de segurança pública. Dilemas, Rio de Janeiro, v. 4, n. 2, p. 229-259, 2011.

MAY, T. Social research: issues, methods and process. 3. ed. Buckingham: Open University Press, 2011.

MINAYO, M. C. S. Violência social sob a perspectiva da saúde pública. Cadernos de Saúde Pública, Rio de Janeiro, v. 10, p. 7-18, 1994. Suplemento 1.

MINAYO, M. C. S.; SOUZA, E.; CONSTANTINO, P. Riscos percebidos e vitimização de policiais civis e militares na (in)segurança pública. Cadernos de Saúde Pública, Rio de Janeiro, v. 23, n. 11, p. 2767-2779, 2007.

MIRANDA, A. P. M.; PITA, M. V. Rotinas burocráticas e linguagens do estado: políticas de registros estatísticos criminais sobre mortes violentas no Rio de Janeiro e em Buenos Aires. Revista de Sociologia e Política, Curitiba, v. 19 , n. 40 , p. $59-81,2011$.

MISSE, D. G. Cinco anos de UPP: um breve balanço. Dilemas, Rio de Janeiro, v. 7, n. 3, p. 675-700, 2014. 
MISSE, M. As ligaçôes perigosas: mercados ilegais, narcotráfico e violência no Rio. Contemporaneidade e Educação, Rio de Janeiro, v. 2, n. 1, p. 93-116, 1997.

MISSE, M.; GRILLO, C. C.; NERI, N. E. Letalidade policial e indiferença legal: a apuração judiciária dos autos de resistência no Rio de Janeiro (2001-2011). Dilemas, Rio de Janeiro, v. 8, p. 43-72, 2015. Edição especial.

MISSE, M.; VARGAS, J. O fluxo do processo de incriminação no Rio de Janeiro na década de 50 e no período de 1997-2001: comparação e análise. In: CONGRESSO BRASILEIRO DE SOCIOLOGIA, 13., 2007, Recife. Anais... Recife: UFPE, 2007. p. 1-16.

MUNIZ, J. Registros de ocorrência da PCERJ como fonte de informaçôes criminais. In: FÓRUM DE DEBATES CRIMINALIDADE, VIOLÊNCIA E SEGURANÇA PÚBLICA NO BRASIL: UMA DISCUSSÃO SOBRE BASES DE DADOS E QUESTÓES METODOLÓGICAS, 1., 2000, Rio de Janeiro. Anais... Rio de Janeiro: Ipea; Ucam, 2000. p. 122-144.

NADANOVSKY, P. O aumento no encarceramento e a redução nos homicídios em São Paulo, Brasil, entre 1996 e 2005. Cadernos de Saúde Pública, Rio de Janeiro, v. 25, n. 8, p. 1859-1864, 2009.

NÓBREGA JÚNIOR, J. M. A dinâmica dos homicídios no Nordeste e em Pernambuco. Dilemas, Rio de Janeiro, v. 3, n. 10, p. 51-74, 2010.

Os homicídios no Nordeste brasileiro. Segurança, Justiça e Cidadania, Brasília, DF, v. 3, n. 6, p. 31-71, 2011.

OLIVEIRA JÚNIOR, A. Dá para confiar nas polícias? confiança e percepção social da polícia no Brasil. Revista Brasileira de Segurança Pública, Sáo Paulo, v. 5, n. 9, p. 6-23, 2011.

OLIVEIRA JÚNIOR, A.; ALENCAR, R. A. A predisposição para chamar a polícia: um estudo sobre a percepção do desempenho e da confiabilidade das instituiçôes policiais. Revista Brasileira de Segurança Pública, São Paulo, v. 9, n. 1, p. 158-170, 2015.

PEIXOTO, B. T.; SOUZA, L. G.; LIMA, R. S. Uma análise sistêmica: vitimização e políticas de segurança em São Paulo. Revista do Serviço Público, Brasília, DF, v. 63, n. 2, p. 217-236, 2012.

PHEBO, L. Impacto da arma de fogo na saúde da população no Brasil. In: FERNANDES, R. C. Brasil: as armas e as vítimas. Rio de Janeiro: 7Letras, 2005. p. 9-36.

PINHEIRO, P. S.; ADORNO, S.; CARDIA, N. Continuidade autoritária e construção da democracia. São Paulo: NEV-USP, 1999.

RAMÃO, F. P.; WADI, Y. M. Espaço urbano e criminalidade violenta: análise da distribuição espacial dos homicídios no município de Cascavel-PR. Revista de Sociologia e Política, Curitiba, v. 18, n. 35, p. 207-230, 2010.

RATTON, J. L.; FERNANDES, F. C. Violência endêmica: homicídios na cidade do Recife: dinâmica e fluxo no sistema de justiça criminal. Revista do Ministério Público de Pernambuco, Recife, v. 6, p. 17-157, 2007. Edição especial. 
RIBEIRO, L. M. L. Administração da justiça criminal na cidade do Rio de Janeiro: uma análise dos casos de homicídios. 2009. Tese (Doutorado em Sociologia) - Instituto Universitário de Pesquisas do Rio de Janeiro, Rio de Janeiro, 2009.

RIBEIRO, L. M. L.; CRUZ, M. V. G.; BATITUCCI, E. C. Liberdade tutelada: a normatização e a burocratizaçâo da transação penal nos Juizados Especiais Criminais: estudo de caso em Belo Horizonte, Minas Gerais. In: ENCONTRO ANUAL DA ANPOCS, 28., 2004, Caxambu. Anais... São Paulo: Anpocs, 2004. p. 1-25.

RIBEIRO, L. M. L.; DUARTE, T. L. O tempo dos tribunais do júri na cidade do Rio de Janeiro: um estudo sobre os padrōes de seleçấo e filtragem para os casos de homicídio doloso julgados entre os anos de 2000 e 2007. Dilemas, Rio de Janeiro, v. 2, n. 3, p. 11-37, 2009.

RIFIOTIS, T. Fluxo da justiça criminal em casos de homicídios dolosos na Regiāo Metropolitana de Florianópolis entre os anos de 2000 e 2003. Florianópolis: Levis, 2006. (Relatório de pesquisa).

RIVERO, P. S. Segregação urbana e distribuição da violência: homicídios georreferenciados no município do Rio de Janeiro. Dilemas, Rio de Janeiro, v. 3, n. 9, p. 117-142, 2010.

RUSCHEL, A. J. Análise do tempo dos processos penais de homicídios no Fórum de Justiça de Florianópolis julgados em 2004. 2006. 196 f. Dissertação (Mestrado em Antropologia Social) - Universidade Federal de Santa Catarina, Florianópolis, 2006.

SANTOS, S. M. et al. Detecção de aglomerados espaciais de óbitos por causas violentas em Porto Alegre, Rio Grande do Sul, Brasil, 1996. Cadernos de Saúde Pública, Rio de Janeiro, v. 17, n. 5, p. 1141-1151, 2001.

SAPORI, L. F. Segurança pública no Brasil: desafios e perspectivas. Rio de Janeiro: FGV, 2007.

SAPORI, L. F.; SENA, L. L.; SILVA, B. F. Mercado do crack e violência urbana na cidade de Belo Horizonte. Dilemas, Rio de Janeiro, v. 5, n. 1, p. 37-66, 2012.

SAPORI, L. F.; WANDERLEY, C. B. A relação entre desemprego e violência na sociedade brasileira: entre o mito e a realidade. Cadernos Adenauer, São Paulo, v. 1, p. 42-73, 2001.

SENRA, N. C. Governamentalidade, a invençâo política das estatísticas. Informare, Rio de Janeiro, v. 2, n. 1, p. 88-95, 1996. . A coordenação da estatística nacional: o equilíbrio entre o desejável e o possivel. 1998. 176 f. Tese (Doutorado em Ciência e Tecnologia) - Universidade Federal do Rio de Janeiro, Rio de Janeiro, 1998.

. Informaçấo estatística: demanda e oferta, uma questão de ordem. DataGramaZero, Rio de Janeiro, v. 1, n. 3, p. A04, 2000.

SILVA, B. F; BEATO FILHO, C. C. Ecologia social do medo: avaliando a associação entre contexto de bairro e medo de crime. Revista Brasileira de Estudos de População, Rio de Janeiro, v. 30, p. 155-170, 2013. Suplemento 1. 
SILVA, G.; BEATO FILHO, C. C. Confiança na polícia em Minas Gerais: o efeito da percepção de eficiência e do contato individual. Opiniäo Pública, Campinas, v. 19, n. 1, p. 118-153, 2013.

SILVA, L. C. Políticas públicas e números: analisando a construção da informação na segurança pública no território do Rio de Janeiro. 2017. Tese (Doutorado em Planejamento Urbano e Regional) - Universidade Federal do Rio de Janeiro, Rio de Janeiro, 2017.

SILVEIRA, A. et al. Impact of the Staying Alive Program on the reduction of homicides in a community in Belo Horizonte. Revista de Saúde Pública, São Paulo, v. 44, n. 3, p. 496-502, 2010.

SKOGAN, W. G. The validity of official crime statistics. Social Science Quarterly, Austin, v. 55, p. 35-48, 1974.

. Reporting crimes to the police: the status of world research. Journal of Research in Crime and Delinquency, New York, v. 21, n. 2, p. 113-137, 1984.

SOARES, G. A. D. Não matarás: desenvolvimento, desigualdade e homicídios. Rio de Janeiro: FGV, 2008.

SOARES, L. E. Violência e politica no Rio de Janeiro. Rio de Janeiro: Relume-Dumará, 1996.

SOUZA, L. A. Criminologia, direito penal e justiça criminal no Brasil: uma revisão da pesquisa recente. Revista Brasileira de Informação Bibliográfica em Ciências Sociais, São Paulo, n. 59, p. 81-108, 2005.

VARGAS, J. Análise comparada do fluxo do sistema de justiça para o crime de estupro. Dados, Rio de Janeiro, v. 50, n. 4, p. 671-697, 2007.

VARGAS, J.; BLAVATSKY, I.; RIBEIRO, L. M. L. Metodologia de tratamento do tempo e da morosidade processual na justiça criminal. Brasília, DF: Ministério da Justiça, 2005.

VASCONCELOS, A. M. N.; COSTA, A. T. M. Demografia da violência: evolução e características. In: PAVANI, A. (Org.). Violência no Distrito Federal. Brasília, DF: Editora UnB, 2005. p. 33-56.

VASCONCELOS, F. T. R. Esboço de uma sociologia politica das ciências sociais contemporâneas (1968-2010): a formaçāo do campo da segurança pública e o debate criminológico no Brasil. 2015. 519 f. Tese (Doutorado em Sociologia) - Universidade de São Paulo, São Paulo, 2015.

WAISELFISZ, J. J. Mapa da violência: os jovens do Brasil. Brasília, DF: Unesco, 2004. v. 4.

ZALUAR, A. Violência e crime. In: MICELI, S. (Org.). O que ler na ciência social brasileira (1970-1995). São Paulo: Anpocs, 1999. p. 13-107.

ZALUAR, A.; MONTEIRO, M. Mortes prematuras e conflito armado pelo domínio das favelas no Rio de Janeiro. Revista Brasileira de Ciências Sociais, São Paulo, v. 28, n. 81, p. 17-31, 2013. 
ZAVERUCHA, J.; NÓBREGA JÚNIOR, J. M. O Pacto pela Vida, os tomadores de decisão e a redução da violência homicida em Pernambuco. Dilemas, Rio de Janeiro, v. 8, n. 2, p. 235-252, 2015.

ZILLI, L. F.; BEATO FILHO, C. C. Gangues juvenis, grupos armados e estruturação de atividades criminosas na Região Metropolitana de Belo Horizonte. Dilemas, Rio de Janeiro, v. 8, p. 73-110, 2015. Edição especial.

\section{Resumo}

\section{Estatísticas oficiais, violência e crime no Brasil}

Neste artigo analisamos os principais problemas e limites metodológicos das pesquisas que utilizaram estatísticas oficiais para explicar fenômenos relacionados a violência, criminalidade e funcionamento do sistema de justiça criminal. Depois de discutir os limites das estatísticas criminais, analisaremos os limites das pesquisas sobre homicídios, vitimizaçáo, confiança, medo e fluxo de justiça. Também discutiremos os principais problemas metodológicos das pesquisas que buscaram avaliar políticas públicas de segurança. Ao final, argumentamos que a principal limitaçáo metodológica dessas pesquisas é a falta de sistemas nacionais de estatísticas sobre violência e criminalidade.

Palavras-chave: Estatísticas Criminais; Homicídios; Pesquisas de Vitimização; Fluxo de Justiça; Políticas Públicas de Segurança.

\section{Abstract}

\section{Official statistics, violence and crime in Brazil}

In this article we analyze the main problems and methodological limits of the research that used official statistics to explain phenomena related to violence, criminality and the functioning of the criminal justice system. After discussing the limits of criminal statistics, we will analyze the research limits on homicide, victimization, confidence, fear, and the flow of justice. We will also discuss the main methodological problems of the research that sought to evaluate public security policies. In the end, we argue that the main methodological limitation of these studies is the lack of national statistics systems on violence and criminality.

Keywords: Criminal Statistics; Homicide; Victimization Surveys; Flow of Justice; Public Security Policies.

\section{Résumé}

\section{Statistiques officielles, violence et criminalité au Brésil}

Dans cet article, on analyse les principaux problèmes et les limites méthodologiques des recherches qui ont utilisé des statistiques officielles afin d'expliquer les phénomènes liés à la violence, criminalité et au fonctionnement du système de justice pénale. Après avoir discuté des limites des statistiques criminelles, on examine les limites de la recherche sur l'homicide, la victimisation, la confiance, la peur et le flux de la justice. On aborde également les principaux problèmes méthodologiques des recherches qui visent à évaluer les politiques publiques de sécurité. En fin de compte, on soutient que la principale limitation méthodologique de ces enquêtes est le manque de systèmes nationaux de statistiques sur la violence et la criminalité.

Mots-clés: Statistiques Criminelles; Homicides; Recherches de Victimisation; Flux de Justice; Politiques Publiques de Sécurité. 